\title{
PCR diagnostics of Chlamydia trachomatis in asymptomatic infection by women
}

\author{
Magdalena Frej-Mądrzak , Anna Gryboś' ${ }^{2}$, Marian Gryboś² , Dorota Teryks-Wołyniec ${ }^{1}$, \\ Agnieszka Jama-Kmiecik ${ }^{1}$, Jolanta Sarowska ${ }^{1}$, Irena Choroszy-Król ${ }^{1}$ \\ ${ }^{1}$ Department of Basic Sciences, Wroclaw Medical University, Wroclaw, Poland \\ ${ }^{2} 1$ st Department and Clinic of Gynaecology and Obstetrics, Wroclaw Medical University, Wroclaw, Poland
}

\begin{abstract}
Objectives: Chlamydial infection is often asymptomatic. The lack of symptoms may result in the infection developing into a chronic. Chlamydial infections of the genitourinary system in women can lead to serious complications like PID, fallopian tubes infertility, ectopic pregnancy, and chronic pelvic pain. An infection of the genitourinary system does not cause any lasting immune resistance and does not protect against re-infection. The aim of this research was to conduct tests for Chlamydia trachomatis on healthy women without any genital system symptoms and to estimate the frequency of asymptomatic infections.

Material and methods: During preventive examinations a cervical smear was obtained from the patients $n=100$. The average age of the patients was $24.86 \pm 3.15$. The swabs were sampled by gynecologists. During the examinations Geneproof PathogenFree DNA isolation Kit and GeneProof Chlamydia trachomatis PCR kit which detects 165 rRNA conservative coding sequence, conservative region of cryptic plasmid DNA, including deletion mutation in cryptic plasmid (Swedish variant).

Results: Swabs were sampled from 100 women aged 18-32 who had no symptoms of chlamydial genitourinary system infection. Within the study group $4 \%$ of women received a positive result, i.e. $4 / 100$.

Conclusions: The study confirmed asymptotic infection in $4 \%$ of women. In own research it was not possible to confirm correlation between the presence of Chlamydia trachomatis and the number of partners or the number of sexual intercourses. Key words: Chlamydia trachomatis, asymptomatic infection in woman, PCR diagnostic
\end{abstract}

Ginekologia Polska 2018; 89, 3: 115-119

\section{INTRODUCTION}

Sexually transmitted infections are a serious issue among women. Chlamydia trachomatis is the most commonly spread STI (Sexually Transmitted Infection) pathogen [1].

In women, Chlamydia trachomatis causes inflammation of the urethra, cervix, fallopian tubes and pelvic organs. Clinical symptoms in women are: mucopurulent inflammation of the cervix, with contact bleeding or without it, cervical tenderness, oedematous cervix, cervical ulcers, inflammation of the urethra, dysuria, vaginal discharge, postcoital bleeding and breakthrough bleeding, difficult to differentiate abdominal pain or lower abdomen pain $[2,3]$.

Chlamydial infection is often asymptomatic, so a person with proctitis or a genital infection may not be aware of its occurrence. The lack of symptoms may result in the infection developing into a chronic condition. Chlamydial infections of the genitourinary system in women can lead to serious complications like pelvic inflammatory disease (PID), which can be a factor causing fallopian tubes infertility, ectopic pregnancy, and chronic pelvic pain [1]. An infection of the genitourinary system does not cause any lasting immune resistance and does not protect against re-infection with Chlamydia trachomatis. In Europe, the Chlamydia trachomatis infection among people aged 18-26 is detected in $3-5.3 \%$ of women and $2.4-7.3 \%$ of men, and $70-95 \%$ of the infections are asymptomatic [4].

Chlamydia trachomatis is usually transmitted through direct contact of a (vaginal, anal) mucous membrane during a sexual intercourse or oral sex or immediately after giving birth through the infected cervical canal of the mother. It is 
estimated that the likelihood of transmission is around 10\% during a single vaginal intercourse and around 55\% with the patients who have had at least two sexual partners within six months. It is highly likely that partners of people infected with Chlamydia trachomatis have also been infected, which is why it is so important to notify them and, subsequently, treat them [4].

Despite some literature reports on spontaneous regressions of chlamydial infections, it is advised to carry out proper examinations in symptomatic and asymptomatic sexually active people, and, after identifying this pathogen, treating infected people along with the partners with whom they have been involved in the last 6 months $[5,6]$.

An indication for performing tests and a risk factor for an infection with Chlamydia trachomatis or other STIs is age 25 or less, new sexual contact in the past year, more than one partner within 24 months, inflammation of the cervix or vaginal discharge in women with risk factors for STIs, acute pelvic pain and/or symptoms of PID, proctocolitis depending on the risk of STIs, diagnosing other STIs; maintaining sexual intercourse with people with STIs or PIDs, terminating pregnancy, and any intrauterine interventions or manipulations [2].

The recommended diagnostic methods are nucleic acid amplification tests (NAATs) that identify Chlamydia trachomatis' DNA or RNA in clinical specimens because of their high sensitivity, specificity, and velocity. When genetic methods of detecting Chlamydia trachomatis are not available, direct fluorescent antibody (DFA) or insulation of Chlamydia trachomatis in cell culture can be used for diagnosis [7, 8].

Treating non complicated infections of the urogenital Chlamydia trachomatis is based on oral administration of doxycycline at a dosage of $100 \mathrm{mg}$ twice a day for 7 days (pregnancy is a contradiction) or a single administration of $1 \mathrm{~g}$ azithromycin. Alternatively, erythromycin is administered orally at a dosage of $500 \mathrm{mg}$ twice a day for 7 days, levofloxacin orally at a dosage of $500 \mathrm{mg}$ once a day for 7 days (pregnancy is a contradiction), or ofloxacin at a dosage of $200 \mathrm{mg}$ twice a day for 7 days (orally; pregnancy is a contradiction) [9].

It is also proposed to introduce multi-drug therapy, which seems to be more effective or natural products, the effectiveness of these methods has not yet been confirmed [10].

According to the recommendation, non-pregnant women $\leq 25$ years old should be examined once a year (especially before the planned pregnancy), but pregnant women should be examined in the first and third trimester of pregnancy (recommended at the first visit). Non-pregnant women aged $>25$ should be examined at least once a year, especially those taking risky sexual behavior (especially before the planned pregnancy), and pregnant women - test in the first trimester of pregnancy (recommended at the first visit), in the third trimester only in women at risk. It is also recommended to test the sexual partner once a year [11].
Unfortunately, the studies are not as applied and the positive results are not reported, which contributes in the spread of asymptomatic infections.

\section{Aim of the study}

The purpose of this research was to conduct tests for Chlamydia trachomatis on healthy women without any genital system symptoms and to estimate the frequency of asymptomatic infections.

\section{MATERIAL AND METHODS}

During preventive examinations a cervical smear was obtained from 100 patients. Swabs were sampled from 100 women aged 18-32 who had no symptoms of chlamydial genitourinary system infection. The average age of the patients was $24.86 \pm 3.15$. From the data collected from the patients, information about the number of partners within the last year before examination and the number of intercourses per week was obtained. Women declared an average of 1.14 partners within the last 24 months and 2.05 intercourses per week. The swabs were sampled by gynecologists. During the examinations Geneproof PathogenFree DNA isolation Kit and GeneProof Chlamydia trachomatis PCR kit which detects $16 \mathrm{~S}$ rRNA conservative coding sequence, conservative region of cryptic plasmid DNA, including deletion mutation in cryptic plasmid (Swedish variant). The experimental protocol and informed consent procedure were in compliance with the Helsinki Convention and were approved by the ethics committee.

\section{RESULTS}

Within the study group $4 \%$ of women received a positive result, i.e. 4/100. All detected infections with Chlamydia trachomatis were asymptotic. On the basis of Pearson correlation coefficient, there was no positive correlation between the number of partners and the occurrence of the infection ( $r=-0.043)$, and, similarly, the number of sexual intercourses did not correlate with the positive result of the test for Chlamydia trachomatis $(r=0.008)$.

\section{Methods of statistical analysis}

Verification of significance of differences between groups PCR $=0$ and PCR $=1$ (women with negative and positive $P(R)$ was carried out using the Statistica 12 package. The study of the significance of differences in the variables examined due to the quantitative nature of the variables was preceded by the verification of the normality of the variable distribution by the Shapiro-Wilk normality test in the cross-sections studied (positive and negative PCR). This test showed, for a variable number of partners and number of contacts, at least one of the examined distributions deviates significantly from the normal one, hence the non-parametric 
U Mann-Whitney test was used for comparisons of 2 subgroups. In turn, the age of two distributions (PCR $=0$ and $P C R=1$ ) did not differ from normal hence the significance of differences comparisons (subject assumption of homogeneity of variance) was used t-test for independent samples.

Descriptive statistics represented by positional measures: average, median, standard deviation (SD), minimum and maximum (Tab. 1).

A significance level of 0.05 was assumed.

There was no statistically significant $(p=0.370)$ difference in age in the group $P C R=0$ and $P C R=1$. In the group with negative results, the average age is 24.8 and differs from the mean by $S D \pm 3.2$ versus mean age 26.3 and $S D \pm 3.1$ in the group with positive PCR (Tab. 2).

There was no statistically significant difference in the number of partners $(p=0.862)$ and the number of contacts ( $p=0.288$ ) by groups of women with negative PCR and positive PCR. In the group with negative PCR, half of the subjects had no more than 1 partner (median) and the other half had no less than 1 partner with the same median in the group with positive PCR. In the group with negative PCR, half of the respondents declared no more than 2.0 contacts (median) and the other half did not less than 2.0 contacts with a median equal to 1.5 in the group with positive PCR (Tab. 3).

\section{DISCUSSION}

Infection with Chlamydia trachomatis in women may not cause any clinical symptoms. The patients that submit to medical check or preventive examinations for this pathogen can detect and confirm a chlamydial infection. In own research, after conducting PCR tests, positive results were obtained in $4 \%$ of the patients. According to some literature reports, the rate of Chlamydia trachomatis infections among women in Europe remains at the level of $3-5.3 \%$. It is confirmed by the results obtained during our research. It is also estimated that $70-95 \%$ of the infected women do not feel any discomfort in the genital system, which aids the uncontrolled spread of this microorganism. Undiagnosed and untreated patients are a potential reservoir of this bacterium [4].

From 2008 to 2013, Bianchi conducted tests using nested PCR which detects chlamydial cryptic plasmid in the cervical smear of women who did not report any clinical

Table 1. Descriptive statistics of study group

\begin{tabular}{|c|c|c|c|c|c|c|c|c|c|}
\hline Descriptive statistics & PCR & $\begin{array}{c}\mathbf{N} \\
\text { significant }\end{array}$ & Average & Median & Minimum & Maksimum & $\begin{array}{l}\text { Lower } \\
\text { quartile }\end{array}$ & $\begin{array}{l}\text { Upper } \\
\text { quartile }\end{array}$ & $\begin{array}{c}\text { SD } \\
\text { (standard } \\
\text { deviation) }\end{array}$ \\
\hline Age & 0 & 97 & 24.8 & 25.0 & 18.0 & 32.0 & 22.0 & 27.0 & 3.2 \\
\hline Number of sex partners & 0 & 97 & 1.2 & 1.0 & 1.0 & 3.0 & 1.0 & 1.0 & 0.5 \\
\hline Number of sex contacts & 0 & 97 & 2.6 & 2.0 & 0.0 & 8.0 & 2.0 & 3.0 & 1.5 \\
\hline Age & 1 & 4 & 26.3 & 27.0 & 22.0 & 29.0 & 24.0 & 28.5 & 3.1 \\
\hline Number of sex partners & 1 & 4 & 1.3 & 1.0 & 1.0 & 2.0 & 1.0 & 1.5 & 0.5 \\
\hline Number of sex contacts & 1 & 4 & 1.8 & 1.5 & 0.0 & 4.0 & 0.5 & 3.0 & 1.7 \\
\hline
\end{tabular}

Table 2. T-test for independent samples of PCR results

\begin{tabular}{|c|c|c|c|c|c|c|c|c|c|c|c|}
\hline $\begin{array}{l}\text { T-test for } \\
\text { independent } \\
\text { samples }\end{array}$ & Average & Average & $\mathbf{t}$ & df & $\mathbf{p}$ & $\begin{array}{c}\mathrm{N} \\
\text { significant }\end{array}$ & $\begin{array}{c}\mathrm{N} \\
\text { significant }\end{array}$ & $\begin{array}{l}\text { SD (standard } \\
\text { deviation) }\end{array}$ & $\begin{array}{l}\text { SD (standard } \\
\text { deviation) }\end{array}$ & quotient $F$ & p \\
\hline PCR & $P C R=0$ & $P C R=1$ & & & & $P C R=0$ & $P C R=1$ & $P C R=0$ & $P C R=1$ & $\begin{array}{c}\text { the } \\
\text { variance }\end{array}$ & $\begin{array}{c}\text { the } \\
\text { variance }\end{array}$ \\
\hline Age & 24.8 & 26.3 & -0.9 & 99 & 0.370 & 97 & 4 & 3.2 & 3.1 & 1.0 & 1.000 \\
\hline
\end{tabular}

$\mathrm{T}$ - result of the test; $\mathrm{df}$ - degrees of freedom; quotient $\mathrm{F}$ - homogeneity test of variance; $\mathrm{p}$ variances — the significance level of the $\mathrm{F}$ test

\begin{tabular}{|l|c|c|c|c|c|c|}
\hline \multicolumn{2}{|l|}{ Table 3. Test U Manna-Whitneya for PCR results } \\
\hline Test U Manna-Whitneya & $\begin{array}{c}\text { Sum.rang } \\
\text { Group 1 } \\
\text { (PCR = 0) }\end{array}$ & $\begin{array}{c}\text { Sum.rang } \\
\text { Group 2 } \\
\text { (PCR = 1) }\end{array}$ & Z & P significant. & $\begin{array}{c}\text { N significant. } \\
\text { Group 2 } \\
\text { Group 1 } \\
\text { (PCR = 0) }\end{array}$ \\
\hline Number of sex partners & 4936.5 & 214.5 & -0.2 & 0.862 & 97 \\
\hline Number of sex contacts & 5008.5 & 142.5 & 1.1 & 0.288 & 97 \\
\hline
\end{tabular}

$Z$ - result of the test 
signs of infection. Author detected the presence of Chlamydia trachomatis in $4.4 \%$ of the patients; he noted the highest rate of infections in women aged $20-21$, i.e. $5.5 \%$, and the lowest rate in the age group 22-23 (3.5\%). The differences between the results obtained in respective age groups by subsequent birth cohorts over the period of the examinations were not significant [12].

Infection with Chlamydia trachomatis detected in woman before pregnancy or at its early stage allows to avoid complications associated with rupture of membranes, preterm birth, and infection of the newborn. In Germany, a research was conducted to analyze the results of the tests for Chlamydia trachomatis obtained over the period 2008-2014. Dudareva-Vizule et al. found that 3.9\% of women are infected with this microorganism. The highest rate of positive results was obtained in the age groups 15-19 (5\%) and 20-24 (4.9\%). Most of the women who underwent the tests were pregnant (41.9\%) and these were preventive examinations. In the age group $<25,26.9 \%$ of women underwent screening tests [13].

The frequency of detecting infections depends on the region of the world and applied diagnostic methods. Reference methods are PCR genetic tests and, in case of limited possibilities of their application, fluorescent immunoassay or ELISA tests are used.

Arsić et al. during research conducted in the Balkan countries, received significantly higher percentage of positive results. Using the ELISA method, Chlamydia trachomatis was detected in 7.1\% (i.e. 100/1400) women in one of the centres while in Skopje, where DFA (direct fluorescent antibody assay) method was used, chlamydia antigen was detected in $6.8 \%(120 / 718)$ patients [14].

In previous own research, testing cervical smears for Chlamydia trachomatis in the years 2012-2013, out of women aged 18-30, by means of the DIF (direct immunofluorescence) method infection was detected in 4/109 patients, i.e. $3.7 \%$. It is a really similar to the current results obtained using the PCR method [15].

One of the partner's infection with Chlamydia leads to a high risk of transmitting that pathogen to the other person during sexual intercourse. It is advised to undergo a test and treat simultaneously all the partners maintaining direct contacts. Berntsson et al. tested 99 women whose partners received a positive result for Chlamydia trachomatis. Using genetic methods they received positive results in 53 out of 99 women (53.5\%); of the women infected with Chlamydia trachomatis half the women did not declare any clinical symptoms, but the other patients experienced dysuria and vaginal discharge [16].

According to PZH (Państwowy Zakład Higieny) in Poland in 2015, 364 cases of chlamydiosis (incidence rate 0.95 per 100 thousand inhabitants) were reported. However, these data do not reflect the facts, because there is no report of all detected infections and the lack of mandatory screening patients below $<25$ years of age [17].

Młynarczyk-Bonikowska et al. examined the coexistence of Neisseria gonorhoeae and Chlamydia trachomatis infections in patients reporting to the Department of Dermatology and Venerology, Warsaw Medical University. Among the 60 women surveyed, including chlamydia infection was 1 patient, and 1 found in co-infections with N. gonorrhoeae. Among all examined men and women who did not manifest on the urogenital tract $(n=79)$, Chlamydia trachomatis was detected in 4 individuals, ie 5.06\% [18].

The number of infected women may depend on the environmental factors that affect the culture and sexual behavior.

Torrone et al. analyzed positive results for Chlamydia trachomatis in the USA between 2007 and 2012. Among sexually active females, prevalence of chlamydia decreased with age $(p<0.05)$. Prevalence among sexually active females aged 14-24 years (the population targeted for chlamydia screening) was $4.7 \%$ overall and varied by race/ethnicity $(p<0.05)$. Among sexually active females aged $14-24$ years, approximately 1 in 7 non-Hispanic black females was infected with chlamydia (13.5\%); 1 in 22 Mexican-American females was infected (4.5\%), and 1 in 55 non-Hispanic white females was infected (1.8\%) [19].

Sacramento et al. conducted research on prevalence of cervical Chlamydia trachomatis infection in sexually active adolescents from Salvador, Brazil. The overall prevalence of cervical Chlamydia trachomatis infection was 31\%. There were no significant differences in the age at first sexual intercourse and condom use between Chlamydia trachomatis infected and uninfected adolescents. About $10 \%$ of the infected women have had five or more sexual partners in their lifetime, while $5.8 \%$ of uninfected patients reported the same. However, this difference was not statistically significant [20].

Our study confirmed asymptotic infection in $4 \%$ of women. In own research it was not possible to confirm correlation between the presence of Chlamydia trachomatis and the number of partners or the number of sexual intercourses. This is due to the small number of patients and too low percentage of positive results.

\section{RESULTS}

Continuation of the tests will undoubtedly allow to estimate and confirm the risk factors for the occurrence of Chlamydia trachomatis infection. Asymptomatic infections are not diagnosed and properly treated, what result further complications of chronic infections. Annual preventive examinations of women and partners would reduce the number of newly infected people. 


\section{Acknowledgement for financial support}

The research was carried out from statutory funds of Wroclaw Medical University No. ST-965.

\section{REFERENCES}

1. Menon S, Timms P, Allan JA, et al. Human and Pathogen Factors Associated with Chlamydia trachomatis-Related Infertility in Women. Clin Microbiol Rev. 2015; 28(4): 969-985, doi: 10.1128/CMR.00035-15, indexed in Pubmed: 26310245.

2. Gouvras G. The European Centre for Disease Prevention and Control. Eurosurveillance. 2004; 9(10): 1-2, doi: 10.2807/esm.09.10.00478-en.

3. 2006 UK National Guideline for the Management of Genital Tract Infection with Chlamydia trachomatis. http://www.nordhavenclinic. co.uk/chlamydia.PDF (2006).

4. Lanjouw E, Ouburg S, de Vries HJ, et al. 2015 European guideline on the management of Chlamydia trachomatis infections. Int J STD AIDS. 2016; 27(5): 333-348, doi: 10.1177/0956462415618837, indexed in Pubmed: 26608577.

5. Sexually Transmitted Diseases Treatment Guidelines, 2010; 59; RR-12. https://www.cdc.gov/mmwr/pdf/rr/rr5912.pdf (2010).

6. Tiplica GS, Radcliffe K, Evans C, et al. 2015 European guidelines for the management of partners of persons with sexually transmitted infections. J Eur Acad Dermatol Venereol. 2015; 29(7): 1251-1257, doi: 10.1111/jdv.13181, indexed in Pubmed: 25951082.

7. Evans R. European Centre for Disease Prevention and Control. Nursing Standard. 2014; 29(9): 30-30, doi: 10.7748/ns.29.9.30.s34.

8. Nwokolo NC, Dragovic B, Patel S, et al. 2015 UK national guideline for the management of infection with Chlamydia trachomatis. Int J STD AIDS. 2016; 27(4): 251-267, doi: 10.1177/0956462415615443, indexed in Pubmed: 26538553.

9. Chojnacka K, Szczapa J, Kędzia W. Częstość perinatalnej transmisji Chlamydia trachomatis i powikłania z nią związane u noworodków przedwcześnie urodzonych. Ginekol Pol. 2012; 83: 116-121.

10. Brown MA, Potroz MG, Teh SW, et al. Natural Products for the Treatment of Chlamydiaceae Infections. Microorganisms. 2016; 4(4), doi: 10.3390/microorganisms4040039, indexed in Pubmed: 27754466.
11. Rekomendacje Polskiego Towarzystwa Ginekologicznego dotyczące zakażeń Chlamydia trachomatis w położnictwie i ginekologii. Ginekol Pol. 2007; 78: 574-575.

12. Bianchi S, Frati ER, Canuti M, et al. Molecular epidemiology and genotyping ofinfection in a cohort of young asymptomatic sexually active women (18-25 years) in Milan, Italy. J Prev Med Hyg. 2016; 57(3): E128-E134, indexed in Pubmed: 27980376.

13. Dudareva-Vizule S, Haar K, Sailer A, et al. Chlamydia trachomatis laboratory sentinel team. Establishment of a voluntary electronic Chlamydia trachomatis laboratory surveillance system in Germany, 2008 to 2014. Euro Surveill. 2017; 22(6), doi: 10.2807/1560-7917.ES.2017.22.6.30459, indexed in Pubmed: 28205505.

14. Arsić $D$, Milovanović $D R$, Ferati $A B$, et al. Monitoring of Chlamydia Trachomatis Genitourinary Infection in Women - Analytical Comparative Study Using Public Health Records from Two Balkan Countries. Cent Eur J Public Health. 2016; 24(1): 16-21, doi: 10.21101/cejph.a4088, indexed in Pubmed: 27070965.

15. Frej-Mądrzak M,Teryks-Wołyniec D, Jama-Kmiecik A, et al. Zakażenia układu moczowo-płciowego oraz spojówek Chlamydia trachomatis u dorosłych i dzieci w latach 2012-2013. Fam Med Prim Care Rev. 2014; 16(3): 222-224.

16. Berntsson $M$, Tunbäck P. Clinical and microscopic signs of cervicitis and urethritis: correlation with Chlamydia trachomatis infection in female STI patients. Acta Derm Venereol. 2013; 93(2): 230-233, doi: 10.2340/00015555-1536, indexed in Pubmed: 23460336.

17. Wojtyniak B, Goryński P, Moskalewicz B. Sytuacja zdrowotna ludności Polski i jej uwarunkowania. Nowotwory. Journal of Oncology. 2013; 63(3): 269-269, doi: 10.5603/njo.2013.0010.

18. Młynarczyk-Bonikowska B, Skulska E, Walter de Walthoffen S, et al. Współistnienie zakażeń Neisseria gonorhoeae i Chlamydia trachomatis u pacjentów zgłaszających się do Kliniki Dermatologii i wenerologii Warszawskiego Uniwersytetu Medycznego. Med Dośw Mikrobiol. 2015; 67: 89-95.

19. Torrone $E$, Johnson $R$, Tian $L$, et al. Prevalence of Neisseria gonorrhoeae Among Persons 14 to 39 Years of Age, United States, 1999 to 2008. Sexually Transmitted Diseases. 2013; 40(3): 202-205, doi: 10.1097/olq.0b013e31827c5a71.

20. Machado MS, Costa e Silva BF, Gomes IL, et al. Prevalence of cervical Chlamydia trachomatis infection in sexually active adolescents from Salvador, Brazil. Braz J Infect Dis. 2012; 16(2): 188-191, doi: 10.1016/s14138670(12)70304-5, indexed in Pubmed: 22552464. 